\title{
Primary cardiac undifferentiated pleomorphic sarcoma: an alarming cause of lower back pain
}

\author{
Risa Hirata, Masaki Tago (ㄷ) , Yoshio Hisata, Shu-ichi Yamashita
}

Department of General Medicine, Saga University Hospital, Saga, Japan

\section{Correspondence to} Dr Masaki Tago; tagomas@cc.saga-u.ac.jp

$\mathrm{RH}$ and MT contributed equally.

Accepted 13 March 2020
D) Check for updates

(C) BMJ Publishing Group Limited 2020. No commercial re-use. See rights and permissions. Published by BMJ.

To cite: Hirata R, Tago M,
Hisata Y, et al. BMJ Case
Rep 2020;13:e235168.
doi:10.1136/bcr-2020-
235168

\section{DESCRIPTION}

A 44-year-old woman presented with lower back pain of 2 months' duration. She developed trouble walking because of severe pain in her right pelvis and thigh, and she visited an orthopaedic clinic 1 week before admission to our hospital. MRI of her lumbar spine revealed several vertebral body tumorous lesions, with the lesion in the second lumbar vertebra extending into the spinal canal (figure 1).

On admission, she had lost $8 \mathrm{~kg}$ of body weight in the previous 2 months. Her respiratory rate was 28 breaths/min, pulse rate: 114 beats/min, and percutaneous oxygen saturation: $98 \%$ on room air. Physical examination revealed an apical systolic murmur and accentuated first heart sound. She could not lie down because of severe pain that did not improve in the supine position. Although her patellar tendon reflexes were brisk, she experienced no bladder or rectal dysfunction. Transthoracic echocardiography showed a mass measuring $2 \mathrm{~cm}$ in diameter on the left atrial wall extending to the posterior leaflet of the mitral valve (figure 2A), which caused

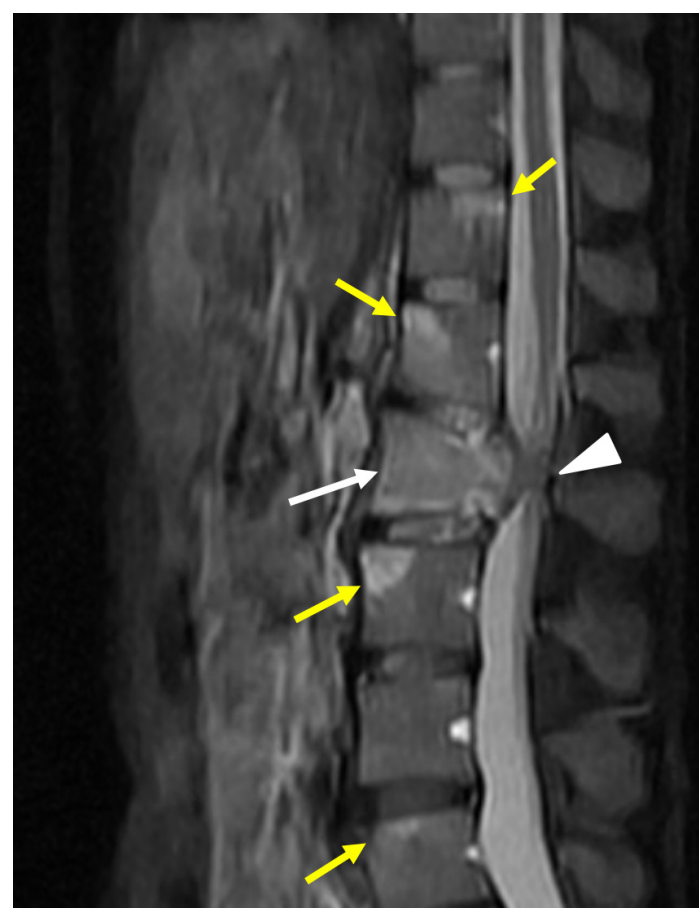

Figure 1 Sagittal T2-weighed MRI of the patient's lumbar spine. T2-weighed image showing high-intensity areas in several vertebral bodies (yellow arrows). The second lumbar vertebra is replaced by a metastatic tumour (white arrow), which extends into the spinal canal (white arrowhead).
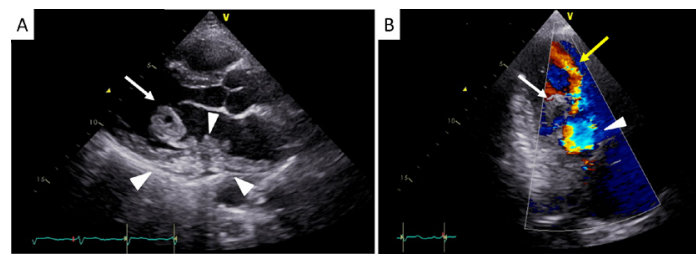

Figure 2 Transthoracic echocardiography findings. (A) Parasternal long-axis, B-mode view showing mass lesion on the left atrial wall (arrowheads) extending to the posterior leaflet of the mitral valve with a $2 \mathrm{~cm}$ diameter mass (arrow). (B) Apical two-chamber view showing a mass lesion on the posterior leaflet of the mitral valve (white arrow). Severe mitral regurgitation (white arrowhead) and ventricular inflow tract obstruction (yellow arrow) are shown by colour Doppler cardiography.

severe mitral valve regurgitation and narrowing of the ventricular inflow tract (figure 2B). Contrastenhanced CT revealed a non-enhanced mass lesion on the atrial wall protruding into the left atrial cavity (figure 3) and a small tumorous lesion in the right upper lung lobe. Multiple osteolytic and osteosclerotic lesions in several bones, including the left ilium, were also detected. Histopathological analysis of the left ilial lesion acquired by CT-guided biopsy showed diffuse proliferation of pleomorphic anaplastic cells and multinucleated giant cells (figure 4) with positive immunostaining for vimentin and negative staining for CD34, $\alpha$-smooth muscle actin, desmin, caldesmon, CD68 and S-100. We diagnosed primary cardiac undifferentiated pleomorphic sarcoma with multiple metastases. Radiation therapy and best supportive care were performed; however, the patient became bedridden and died 5 months later.

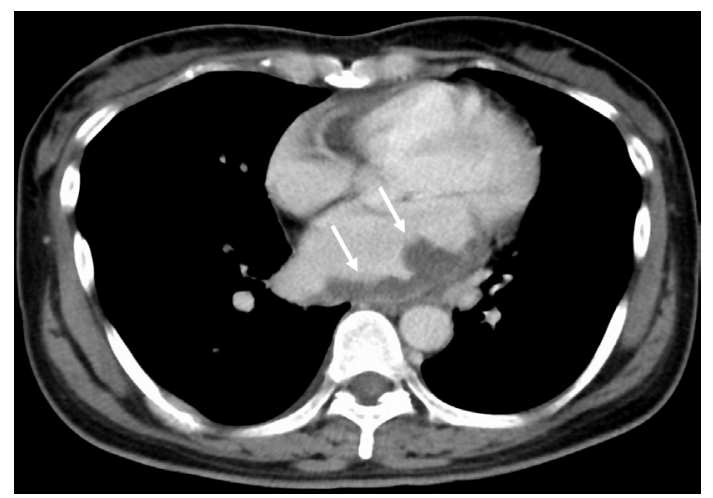

Figure 3 Whole-body CT with contrast enhancement. A non-enhanced mass lesion is seen on the left atrial wall that protrudes into the left atrial cavity (arrows). 


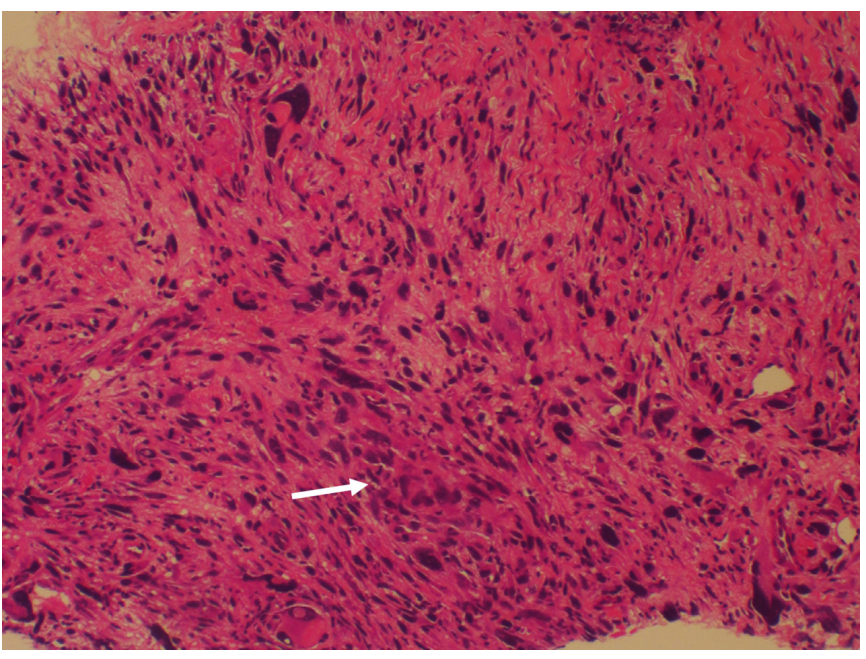

Figure 4 Histopathological findings of the left ilial lesion acquired by CT-guided biopsy (H\&E staining, high power field). The photomicrograph shows diffuse proliferation of pleomorphic anaplastic cells and multinucleated giant cells (white arrow).

Primary cardiac tumours are rare and have a reported frequency of 1.38 per 100000 population per year. ${ }^{1}$ These tumours are found in $0.0017 \%-0.02 \%$ of autopsy cases ${ }^{23}$ and have an incidence of malignancy of approximately $9.5 \% .{ }^{1}$ The earliest manifestation in our patient with primary cardiac undifferentiated pleomorphic sarcoma was lower back pain secondary to the bone metastases, which was a remarkable presentation. Usually, the first complaint is a symptom of heart failure such as dyspnoea $^{4}$; lower back pain as the first manifestation is extremely rare and reported in few previous case reports. ${ }^{5-7}$ Although lower back pain itself is a common manifestation caused by nonserious orthopaedic diseases, some serious medical disorders such as malignancies could be its cause, ${ }^{8}$ and 'red flag' signs are essential to determine whether presenting back pain is serious." Our patient had three red flags, namely, unintentional weight loss, pain without improvement by resting in the supine position and neurological deficits, ${ }^{10}$ leading us to perform a meticulous physical examination, which resulted in finding signs of cardiac abnormalities and timely echocardiography, to make a correct diagnosis.

\section{Learning points}

- Lower back pain could be a rare but possible first manifestation of a primary cardiac malignant tumour.

- It is essential to find the red flag signs with lower back pain using detailed medical interviews and meticulous physical examinations.

Acknowledgements We thank Tomoyo Nishi and Yoshimasa Oda from Department of General Medicine, Saga University Hospital for supporting this work involved in clinical care of the patient. We also thank Jane Charbonneau, DVM, from Edanz Group (www.edanzediting.com/ac) for editing a draft of this manuscript.

Contributors RH: involved in literature search,drafting and clinical care of the patient. MT: involved in literature search, concept and drafting. $\mathrm{YH}$ : involved in literature search, drafting and clinical care of the patient. SY: involved in concept and revision of article.

Funding The authors have not declared a specific grant for this research from any funding agency in the public, commercial or not-for-profit sectors.

Competing interests None declared.

Patient consent for publication Next of kin consent obtained.

Provenance and peer review Not commissioned; externally peer reviewed.

ORCID iD

Masaki Tago http://orcid.org/0000-0003-1092-1834

\section{REFERENCES}

1 Cresti A, Chiavarelli M, Glauber M, et al. Incidence rate of primary cardiac tumors: a 14-year population study. J Cardiovasc Med 2016;17:37-43.

2 Elbardissi AW, Dearani JA, Daly RC, et al. Survival after resection of primary cardiac tumors: a 48-year experience. Circulation 2008;118:S7-15.

3 Butany J, Nair V, Naseemuddin A, et al. Cardiac tumours: diagnosis and management. Lancet Oncol 2005:6:219-28.

4 Taguchi S. Comprehensive review of the epidemiology and treatments for malignant adult cardiac tumors. Gen Thorac Cardiovasc Surg 2018;66:257-62.

5 Alsara 0, Rayamajhi S, Ghanem F, et al. Primary cardiac pleomorphic sarcoma presenting as back pain in an 18-year-old man. Tex Heart Inst J 2013;40:339

6 Itoh A, Okubo S, Nakanishi N, et al. Recurrent epicardial fibrosarcoma which arose 12 years after the first resection. Eur Heart J 1991;12:270-2.

7 Ishikawa K, Hirata S, Fukuzumi N. Malignant neurilemmoma of left atrium. Br Heart J 1982;47:94-7

8 Wáng YXJ, Wu A-M, Ruiz Santiago F, et al. Informed appropriate imaging for low back pain management: a narrative review. J Orthop Translat 2018;15:21-34.

9 Lurie JD. What diagnostic tests are useful for low back pain? Best Pract Res Clin Rheumatol 2005;19:557-75.

10 Casser HR, Seddigh S, Rauschmann M. Acute lumbar back pain: investigation, differential diagnosis, and treatment. Dtsch Arzteb/ Int 2016;113:223.

Copyright 2020 BMJ Publishing Group. All rights reserved. For permission to reuse any of this content visit

https://www.bmj.com/company/products-services/rights-and-licensing/permissions/

BMJ Case Report Fellows may re-use this article for personal use and teaching without any further permission.

Become a Fellow of BMJ Case Reports today and you can:

- Submit as many cases as you like

- Enjoy fast sympathetic peer review and rapid publication of accepted articles

- Access all the published articles

Re-use any of the published material for personal use and teaching without further permission

Customer Service

If you have any further queries about your subscription, please contact our customer services team on +44 (0) 2071111105 or via email at support@bmj.com.

Visit casereports.bmj.com for more articles like this and to become a Fellow 